\title{
Convergence of Market Concentration: Evidence from Czech Food Processing Sectors
}

\section{Blažková}

Faculty of Regional Development and International Studies, Mendel University in Brno, Czech Republic

\begin{abstract}
The aim of the paper is to evaluate the market concentration in the Czech food and beverages industry over the period of 2003-2014, to quantify disparities among particular sectors and to investigate the trend of market concentration. The concept of convergence is applied when investigating the trend in the long term. The market concentration in the Czech food and beverages industry has increased on average. In sectors with relatively low market concentration in 2003, the values of concentration increased more rapidly after 2003. On the contrary, the most concentrated sectors tend to change slowly over time and the concentration in some sectors even declined. On the basis of the absolute $\beta$-convergence model estimation, it was concluded that there is a trend for convergence of the market concentration in the long run to one and the same point for all sectors of the industry.
\end{abstract}

\section{Keywords}

Market concentration, food and beverages industry, concept of convergence.

Blažková, I. (2016) "Convergence of Market Concentration: Evidence from Czech Food Processing Sectors ", AGRIS on-line Papers in Economics and Informatics, Vol. 8, No. 4, pp. 25 - 36. ISSN 1804-1930. DOI 10.7160/aol.2016.080403.

\section{Introduction}

Agribusiness sector is undergoing significant changes - changes in market structures on agribusiness markets, in geographic location of production and processing, changes in characteristics of agricultural and food products, in global distribution and consumption and changes in technologies. These changes have impact on the increase in concentration in the food processing sector (Rogers, 2001) and primarily in the retail sector (McCorriston, 2002; Reardon et al., 2003), on the increasing emphasis on product quality and food safety (Saitone and Sexton, 2010) and on the rapid growth of vertical coordination and integration (MacDonald and Korb, 2011; Swinnen and Maertens, 2007).

At present, the key players on the food markets are multinational corporations. As reported by Daniels (2008), the structure and quality of food produced is determined by supermarkets and other transnational actors, often organized into large corporations, which currently can easier succeed in the competition, pricing policies and legislation regarding food quality and safety than small local enterprises. Implications of these features on the changing patterns of competition and the impact on food producers, supplier competition and economic welfare are discussed by many authors, e.g. Dobson et al. (2003), Regmi and Gehlhar (2005), Boehlje,et al. (2011), Sexton (2012).

The recent literature states that concentration and consolidation takes place in both food processing industry and retailing sector through mergers and acquisitions (Dobson et al., 2003; Swinnen and Vandeplas, 2010); where large food companies are also increasingly spreading globally through foreign direct investments, which contributes to increased concentration outside their home markets, as mentioned by Clarke et al. (2002).

The market concentration is of interest to economists in the long-term due to its possible effects on the efficiency and welfare of the economy. There are arguments supporting the positive impact of high concentration on the efficiency of the firms in the market, and on the other hand, arguments against the high concentration exist as well.

Basic economic theory suggests that high market concentration will lead to market power and thus inefficiencies, since the possible existence of market power of large enterprises may lead to lower competition, higher prices and cause 
welfare losses. Swinnen and Vandeplas (2010) even used the term "double market power" for the situation - when companies in concentrated sectors use their buyer power to negotiate lower prices from suppliers, but also use their selling power toward customers or downstream industries to impose higher customer prices than in the competitive case. However, as some authors argue, higher market concentration does not necessarily mean high market power and the abuse of this power, and on the contrary, it may improve welfare (e.g. Clarke et al., 2002; Shervani et al., 2007). Higher concentration means the use of economies of scale in the production of a single product and the economies of scope in the production of multiple products, which has a positive effect on costs of the firms. A certain degree of concentration may be also necessary for investments in research and innovation. Moreover, the effect of concentration on efficiency and prices depends on the rest of the commodity vertical - for example, retail concentration may lead to lower consumer prices due to higher buyer power and better bargaining position of retail towards suppliers, which occurred in the Czech Republic after the entry of multinational retail chains into the Czech market and resulted in a beneficial situation for end consumers with regard to lower price and increased variety of food (Blažková and Chmelíková, 2014).

As stated by Sexton (2012), farmer and consumer welfare as well as the general welfare are linked to the competitive structure in the upand downstream areas of agriculture. Boehlje et al. (2011) emphasized that consolidation and alteration of vertical and horizontal limits of firms in food and agribusiness sector affect vast parts of the supply chain. There is evidence that large retailers and food companies are depressing farm prices as a result of their market power (Swinnen and Vandeplas, 2010). Therefore, increased concentration and market power caused the competition policy in agri-food chains to be an important issue.

Agribusiness firms in the Czech Republic are facing ongoing changes in competition and market conditions. While the decrease of the number of firms and the development of market concentration in the whole manufacturing industry and in the retail sector has been subjected to research (see e.g. Zemplinerová and Stibal, 1994; Dries et al., 2004), the development of market concentration in the food industry seems to be less investigated (see e.g. Blažková and Chmelíková, 2014).

This paper deals with the trend of market concentration on the food processing market, which can have a significant influence on the development of relations and the price formation at different levels of the commodity verticals, as mentioned by Blažková and Chmelíková (2014). The aim of the paper is to evaluate the market concentration in the Czech food and beverages industry, to quantify disparities among particular sectors of the food and beverages industry and to investigate the trend of market concentration. The question that should be answered when concerning the evolution of the market concentration on the Czech food and beverages market is whether the dispersion of this variable across particular sectors tends to decrease over time. Or, in other words, whether sectors with lower market concentration tend to catch up with sectors with higher market concentration. The concepts of convergence implicit in these questions are called $\sigma$-convergence and $\beta$-convergence (Sala-i-Martin, 1996). Although these concepts are primarily used and applied in determination of the convergence of per-capita income or product across countries or regions, in practice a number of other variables can enter a convergence model significantly (e.g. market concentration as presented in this paper).

While previous studies have looked at market concentration on selected markets in the Czech Republic, no study to my knowledge comprehensively investigated market structure measures within this important stage of the commodity vertical - food and beverages industry. Previous studies either focused on a single sector of the Czech food and beverages industry (e.g. Řezbová et al. (2015) focused on the sugar market or Čechura et al. (2015) examined dairy industry), or observed the whole manufacturing industry (e.g. Zemplinerová and Stibal, 1994). Thus, the results of the analysis of market concentration development and trend in the Czech food and beverages industry can be seen as worthwhile. Describing and explaining the development of market concentration and its distribution across sectors could provide a view of the competitive situation in agribusiness, answer the questions about the possible evolution of the market structure in the future and therefore, provide some suggestions that can be of interest to policy makers with respect to competition and industrial policy.

\section{Materials and methods}

\section{Data}

The empirical analysis is based mainly on the data obtained from the database Albertina Gold Edition (Bisnode, 2015). The dataset covers 
the period from 2003 to 2014 and includes final accounts of enterprises operating in the Czech food and beverages industry. Markets are defined based on the 3-digit level of the Classification of Economic Activities (CZ-NACE). The sample is made of 13,667 observations across 12 years and 10 food sectors in the Czech Republic, namely CZ-NACE 101 Production, processing, preserving of meat and meat products; CZ-NACE 102 Processing and preserving of fish and fish products; CZ-NACE 103 Processing and preserving of fruit and vegetables; CZ-NACE 104 Manufacture of vegetable and animal oils and fats; CZ-NACE 105 Manufacture of dairy products; CZ-NACE 106 Manufacture of grain mill products, starches and starch products; CZ-NACE 107 Manufacture of bakery and farinaceous products; CZ-NACE 108 Manufacture of other food products; CZ-NACE 109 Manufacture of prepared animal feeds; CZ-NACE 110 Manufacture of beverages. All firms with main activities in any official CZ-NACE food and beverages industry that had available data were considered.

The shares of observations by sectors in the sample with those in the population are compared in Table 1 to see whether the sample adequately represents the population of Czech food processing firms and that representation of observations is evenly distributed to all subsectors. The size distribution of the enterprises in the sample is shown in Table 2 that reports the average shares of observations in particular size groups of enterprises within the subsectors over the years 2003-2014. Companies are classified in four size groups defined according to the number of persons employed - with $0-19$, $20-49,50-249$ and 250 or more persons employed. It follows from Table 2 that representativeness of the sample is strengthened by including also small enterprises (with 0-19 persons employed) in the analysis $(49.7 \%$ observations in the analysed sample), since they are in the food industry represented in large numbers.

In order to have information on total sales of own products and services for particular sectors, the data published by the Ministry of Agriculture of the Czech Republic (Ministry of Agriculture of the Czech Republic, 2008; Ministry of Agriculture of the Czech Republic, 2015) were employed.

\begin{tabular}{|c|c|c|c|c|c|c|c|c|c|c|c|c|}
\hline \multirow[b]{2}{*}{ CZ-NACE } & \multicolumn{2}{|c|}{2003} & \multicolumn{2}{|c|}{2004} & \multicolumn{2}{|c|}{2005} & \multicolumn{2}{|c|}{2006} & \multicolumn{2}{|c|}{2007} & \multicolumn{2}{|c|}{2008} \\
\hline & $\begin{array}{l}\text { Population } \\
(\mathrm{N}=6,326)\end{array}$ & $\begin{array}{l}\text { Sample } \\
(\mathrm{N}=691)\end{array}$ & $\begin{array}{l}\text { Population } \\
(\mathrm{N}=6,317)\end{array}$ & $\begin{array}{l}\text { Sample } \\
(\mathrm{N}=828)\end{array}$ & $\begin{array}{l}\text { Population } \\
(\mathrm{N}=6,630)\end{array}$ & $\begin{array}{l}\text { Sample } \\
(\mathrm{N}=931)\end{array}$ & $\begin{array}{l}\text { Population } \\
(\mathrm{N}=6,550)\end{array}$ & $\begin{array}{l}\text { Sample } \\
(\mathrm{N}=1007)\end{array}$ & $\begin{array}{l}\text { Population } \\
(\mathrm{N}=6,560)\end{array}$ & $\begin{array}{l}\text { Sample } \\
(\mathrm{N}=1116)\end{array}$ & $\begin{array}{l}\text { Population } \\
(\mathrm{N}=6,351)\end{array}$ & $\begin{array}{l}\text { Sample } \\
(\mathrm{N}=1,161)\end{array}$ \\
\hline 101 & 15.7 & 16.6 & 18.2 & 17.5 & 16.5 & 16.2 & 16.4 & 15.2 & 16.1 & 15.1 & 18.9 & 15.7 \\
\hline 102 & 0.8 & 1.4 & 0.5 & 1.6 & 0.3 & 1.4 & 0.3 & 1.2 & 0.4 & 1.2 & 0.3 & 1.1 \\
\hline 103 & 2.2 & 2.9 & 1.6 & 3.5 & 3.3 & 3.2 & 3.4 & 3.3 & 3.3 & 3.1 & 2.2 & 3.1 \\
\hline 104 & 0.3 & 1.3 & 0.3 & 1.2 & 0.3 & 1.1 & 0.3 & 0.9 & 0.3 & 1.1 & 0.3 & 1.0 \\
\hline 105 & 5.7 & 8.7 & 5.0 & 8.0 & 3.0 & 6.8 & 2.9 & 6.7 & 2.9 & 6.5 & 2.5 & 5.9 \\
\hline 106 & 4.6 & 5.4 & 2.6 & 4.7 & 2.2 & 4.6 & 2.2 & 4.5 & 2.2 & 4.3 & 2.0 & 4.2 \\
\hline 107 & 41.9 & 22.0 & 41.8 & 22.7 & 41.9 & 24.6 & 41.4 & 25.4 & 40.6 & 25.9 & 36.4 & 25.5 \\
\hline 108 & 11.7 & 15.5 & 13.2 & 15.1 & 13.8 & 15.7 & 14.2 & 16.7 & 15.1 & 17.2 & 17.3 & 17.7 \\
\hline 109 & 3.3 & 8.0 & 3.0 & 7.7 & 3.7 & 8.2 & 3.9 & 7.6 & 3.8 & 7.3 & 3.8 & 7.4 \\
\hline 110 & 13.8 & 18.2 & 13.8 & 18.0 & 15.2 & 18.3 & 15.1 & 18.6 & 15.3 & 18.4 & 16.3 & 18.2 \\
\hline CZ-NACE & $\begin{array}{l}20 \\
\text { Population } \\
(\mathrm{N}=6,829) \\
\end{array}$ & $\begin{array}{l}9 \\
\text { Sample } \\
(\mathrm{N}=1,487)\end{array}$ & $\begin{array}{l}20 \\
\text { Population } \\
(\mathrm{N}=7,740) \\
\end{array}$ & $\begin{array}{l}\text { Sample } \\
(\mathrm{N}=1,526)\end{array}$ & $\begin{array}{l}20 \\
\text { Population } \\
(\mathrm{N}=8,362) \\
\end{array}$ & $\begin{array}{l}11 \\
\text { Sample } \\
(\mathrm{N}=1,430)\end{array}$ & $\begin{array}{l}\text { Population } \\
(\mathrm{N}=8,527) \\
\end{array}$ & $\begin{array}{l}12 \\
\text { Sample } \\
(\mathrm{N}=1,374) \\
\end{array}$ & $\begin{array}{l}20 \\
\text { Population } \\
(\mathrm{N}=8,432)\end{array}$ & $\begin{array}{l}13 \\
\text { Sample } \\
(\mathrm{N}=1,173) \\
\end{array}$ & $\begin{array}{l}20 \\
\text { Population } \\
(\mathrm{N}=8,806) \\
\end{array}$ & $\begin{array}{l}14 \\
\text { Sample } \\
(\mathrm{N}=942)\end{array}$ \\
\hline 101 & 18.2 & 14.9 & 18.6 & 14.9 & 20.2 & 15.1 & 20.1 & 15.2 & 20.3 & 16.2 & 20.2 & 15.4 \\
\hline 102 & 0.3 & 0.9 & 0.3 & 0.9 & 0.3 & 1.0 & 0.3 & 0.7 & 0.3 & 0.8 & 0.2 & 0.7 \\
\hline 103 & 2.1 & 2.9 & 2.1 & 2.9 & 1.9 & 2.7 & 1.7 & 2.9 & 1.6 & 3.2 & 1.5 & 3.6 \\
\hline 104 & 0.3 & 1.0 & 0.3 & 0.9 & 0.3 & 1.0 & 0.2 & 1.1 & 0.2 & 1.1 & 0.2 & 1.3 \\
\hline 105 & 2.4 & 4.8 & 2.7 & 4.8 & 2.4 & 4.6 & 2.2 & 4.3 & 2.1 & 4.3 & 2.1 & 4.4 \\
\hline 106 & 2.1 & 4.6 & 2.1 & 4.6 & 2.1 & 4.1 & 2.4 & 4.8 & 2.3 & 4.8 & 2.5 & 4.4 \\
\hline 107 & 37.3 & 25.9 & 35.0 & 25.8 & 35.6 & 25.9 & 34.9 & 25.2 & 35.1 & 22.9 & 34.5 & 25.2 \\
\hline 108 & 16.9 & 19.7 & 18.1 & 20.1 & 17.2 & 20.9 & 19.1 & 21.4 & 18.8 & 21.2 & 20.2 & 19.2 \\
\hline 109 & 4.1 & 7.3 & 4.9 & 7.4 & 4.9 & 7.5 & 4.7 & 7.1 & 4.4 & 7.2 & 4.1 & 7.6 \\
\hline 110 & 16.3 & 18.2 & 15.9 & 17.8 & 15.1 & 17.3 & 14.3 & 17.2 & 15.0 & 18.4 & 14.4 & 18.3 \\
\hline
\end{tabular}

Note: Population refers to all firms active in the Czech food and beverages industry.

Source: own calculation based on Bisnode (2015) and Ministry of Agriculture of the Czech Republic (2008, 2015)

Table 1: Shares of observations by subsector within the population and in the sample (\%). 


\begin{tabular}{|l|c|c|c|c|}
\hline & $0-19$ & $20-49$ & $50-249$ & $250+$ \\
\hline CZ-NACE 101 & 47.70 & 22.42 & 21.46 & 8.42 \\
\hline CZ-NACE 102 & 45.48 & 25.53 & 23.47 & 5.52 \\
\hline CZ-NACE 103 & 44.49 & 19.01 & 31.22 & 5.28 \\
\hline CZ-NACE 104 & 38.19 & 22.62 & 24.59 & 14.60 \\
\hline CZ-NACE 105 & 31.71 & 11.38 & 43.79 & 13.12 \\
\hline CZ-NACE 106 & 49.00 & 17.37 & 33.63 & 0.00 \\
\hline CZ-NACE 107 & 46.44 & 22.33 & 23.84 & 7.39 \\
\hline CZ-NACE 108 & 48.74 & 21.26 & 24.86 & 5.14 \\
\hline CZ-NACE 109 & 46.84 & 23.11 & 23.78 & 6.27 \\
\hline CZ-NACE 110 & 62.07 & 14.63 & 18.87 & 4.43 \\
\hline
\end{tabular}

Source: own calculation based on Bisnode (2015)

Table 2: The size distribution of the enterprises in the sample (\%)

\section{Variables}

Market concentration was calculated in the Czech food and beverages industry as a whole and within the particular food sectors. Market concentration was expressed by two most common measures of concentration - the Concentration Ratio (hereinafter referred to as " $C R m$ ") and the Herfindahl-Hirschman Index (hereinafter referred to as " $H H T^{\prime}$ "). To determine the market structure, it is advisable to use both indicators that complement each other - while $\mathrm{CRm}$ describes the market share of $m$ largest companies in the industry, $H H I$ shows the inequality of distribution of market shares among all firms in the industry.

The concentration ratio for four largest firms (CR4) in the whole Czech food processing industry and in particular subsectors was calculated as the percentage of market shares held by four largest firms in an industry (Viscusi et al., 2005). The Herfindahl-Hirschman Index (HHI) was calculated as the sum of the squares of the market shares of the firms within the industry (Viscusi et al., 2005), where the market shares are expressed as fractions. The formulas for the overall $C R 4$ and $H H I$ in the Czech food processing industry are as follows:

$$
\begin{aligned}
& \text { CR4 }=\sum_{i=1}^{4} S_{i} \\
& H H I=\sum_{i=1}^{n}\left(S_{i}\right)^{2}
\end{aligned}
$$

where $S_{i}$ denotes the individual market share, i.e. the percentage of the $i$-th firm in the Czech food processing industry calculated as the production of the $i$-th firm divided by the sum of production of all firms in the Czech food processing industry and $n$ denotes number of firms in the industry, for which $H H I$ is calculated.

The formulas for subsectoral $C R 4$ and $H H I$ are as follows:

$$
\begin{aligned}
& C R 4 j=\sum_{i=1}^{4} S_{i j} \\
& H H I_{j}=\sum_{i=1}^{n}\left(S_{i j}\right)^{2}
\end{aligned}
$$

where $S_{i j}$ denotes the individual market share, i.e. the percentage of the $i$-th firm in the $j$-th subsector of the Czech food processing industry calculated as the production of the $i$-th firm in the $j$-th subsector divided by the sum of production of all firms in the $j$-th subsector of the Czech food processing industry and $\mathrm{n}$ denotes number of firms in the $j$-th subsector, for which $H H I$ is calculated.

In this paper, the market concentration was calculated on the basis of sales data, i.e. sales of own products and services, because this indicator seems to explain more about the market share than the output. For the concentration ratio it is valid that the higher $C R 4$ is, the higher market power is concentrated among the four largest firms. The higher the $H H I$ is, the higher the inequality among market shares of firms is, in other words, the situation is distinct from equal market shares. $H H I$ index ranges from 0 (no concentration and highly competitive system) to 10,000 (pure monopoly).

Table 3 shows that the data is relatively heterogeneous, with high standard deviations and coefficients of variation for the variables. The average of $C R 4$, which is $38.58 \%$, can be considered as loose oligopoly, the average $H H I$ classifies the food sectors as an unconcentrated market with significant positions of several 


\begin{tabular}{|l|c|c|c|c|c|}
\hline & Mean & Standard Deviation & Coefficient of Variation & Minimum & Maximum \\
\hline CR4 & 39.27 & 19.54 & 49.75 & 12.58 & 96.24 \\
\hline HHI & 928.15 & 1281.09 & 138.03 & 85.46 & 6332.12 \\
\hline
\end{tabular}

Source: Bisnode (2015), Ministry of Agriculture of the Czech Republic (2008, 2015) - own calculation

Table 3: Descriptive statistics of the variables in the period of 2003-2014.

companies (according to the Horizontal Merger Guidelines (U.S. Department of Justice and the Federal Commission, 2010) ${ }^{1}$ ).

\section{Methods}

To assess the trend of market concentration in the markets for all sectors of the food and beverages industry in the Czech Republic, the theory of absolute $\beta$-convergence was used - as described by Sala-i-Martin (1996) and used e.g. by Setiawan et al. (2012). Based on this theory it is investigated whether there is a tendency for the market concentration in the Czech food and beverages industry to move to a certain value. The absolute convergence model can assess whether there is a trend for the convergence of the market concentration in the long run to one and the same point for all sectors of the industry, i.e. whether there is a tendency towards the equalisation of concentration ratios within the sample. The assumption about the same stable state of particular sectors in the long run is relevant due to the fact that all sectors in the Czech economy face the same business characteristics at the same time.

The absolute $\beta$-convergence approach was verified by an econometric modelling technique, namely with the use of cross-sectional linear regression analysis. Cross-sectional regression is drawn by an effort find out whether the convergence process is present among particular sectors within the Czech food processing industry or there are more divergence tendencies. For the analysed sectors, annual time series of two indicators of market concentration were used - CR4 and HHI.

The absolute $\beta$-convergence model of cross-section data for the sectors is as follows:

$$
\frac{\operatorname{Ln} M S_{t_{n}}^{j}-\operatorname{Ln} M S_{t_{0}}^{j}}{T}=\beta_{0}-\beta_{1} \operatorname{Ln} M S_{t_{0}}^{j}
$$

\footnotetext{
${ }^{1}$ According to the classification defined by the US Department of Justice and the Federal Trade Commission (2010), HHI lower than 100 means a highly competitive market, $H H I$ ranging from 100 to 1,500 indicates an unconcentrated market with significant positions of several companies, the values of the $H H I$ from 1,500 to 2,500 reveals significant market concentration (mostly monopolistic competition) and $H H I$ above 2,500 indicates a highly concentrated market (mostly oligopoly). $H H I$ close to 10,000 suggests a monopoly.
}

where $j=1,2, \ldots 10$ indexes sectors, $t_{0}$ is the initial year of observation, i.e. 2003, and $t_{n}$ is the last year of observation, i.e. 2014. $\mathrm{MS}_{\mathrm{t}}^{\mathrm{j}}$ is the market structure of the sector $j$ in the period $t$, which is represented by either $C R 4$ or by $H H I$. The parameters of the linear regression model of the cross-section data are estimated using the least-squares method (OLS). According to the theory of absolute convergence, sectors show convergence in market structure if the estimated coefficient of $\beta_{1}$ is positive. Statistical data, calculations and graphs were processed with the use of the software Gretl. Statistical significance of the model was tested using the F-test. Individual model parameters were tested by the t-test. Model (for both $C R 4$ and $H H I$ ) as a whole is statistically significant at $5 \%$ level of significance. The econometric verification included the White Heteroskedasticity test and Jarque-Bera test of residuals normality. No multicolinearity was detected. At the $5 \%$ level of statistical significance the model can be considered homoscedastic and normal distribution of residuals is observed.

\section{Results and discussion}

The general concentration in the Czech food and beverages industry in the period 2003-2014 grew (see Table 4) even though the number of firms increased in this industry. The number of food enterprises increased between 2003 and 2014 by around 39\% (Ministry of Agriculture of the Czech Republic, 2015; Ministry of Agriculture of the Czech Republic, 2008). The increase was observed in all sectors of the industry, the most significant increase was in the number of enterprises operating in the sector of meat processing (CZ-NACE 101), in the sector of manufacture of prepared animal feeds (CZ-NACE 109) and in the sector of manufacture of other food products (CZ-NACE 108), where the number of enterprises has approximately doubled.

Nevertheless, the concentration in the Czech food and beverages industry is still low in comparison with the subsequent vertical stage, i.e. retail (CR5 indicator was $14.45 \%$ in the Czech food and beverages industry in comparison with $45.50 \%$ 
in the Czech retail sector in 2013). As stated by Blažková and Chmelíková (2014), this fact causes the Czech food processing enterprises to often accept the disadvantageous delivery terms and conditions including various fees for introduction of goods into chains of stores, participation in advertising, or suffering long maturity invoices. At the same time, the food processors are under pressure to supply wholesale prices and quality. On the other hand, from the perspective of end consumers, the concentrated market structure of final segments of agribusiness may show a positive element in the short-term period, as explained by Bečvářová (2007). According to Bečvářová (2007), the positive impact of an imperfectly competitive environment on the consumer surplus due to the savings from a large-scale production and higher work productivity based on the modernization of production facilities and faster application of the results of research and development in large enterprises was observed on the markets of transitive economic systems such as the Czech Republic.
Based on the analysis, it can be concluded that the concentration process is different depending on the sector (see Table 5). The box-andwhisker diagrams in Figures 1, 2, 3 and 4 depict the subsectoral $C R 4$, resp. $H H I$, distribution across time (see Figure 1, resp. 2) and CR4, resp. HHI, distribution across subsectors in the period 2004-2014 (see Figure 3, resp. 4). The bottom and top of the box represent the first and third quartiles, the band inside the box is the median, and the ends of the whiskers represent the minimum and maximum of the data.

The degree of dispersion of the values of $C R 4$ indicator among sectors within particular years is relatively stable (see Figure 1), in the case of $H H I$ the dispersion among sectors is slowly increasing in the recent years (see Figure 2). The outlier, which can be seen in both Figures 1 and 2, is the sector of manufacture of vegetable and animal oils and fats (CZ-NACE 104), which is highly concentrated in the whole observed period (the indicator CR4 was $92.53 \%$ in 2014) - on the Czech market there are only a few large enterprises.

\begin{tabular}{|l|r|c|c|c|c|c|c|c|c|c|c|c|}
\hline & 2003 & 2004 & 2005 & 2006 & 2007 & 2008 & 2009 & 2010 & 2011 & 2012 & 2013 & 2014 \\
\hline$C R 4[\%]$ & 9.81 & 10.01 & 10.86 & 11.61 & 11.24 & 10.41 & 11.57 & 11.29 & 11.30 & 11.85 & 12.07 & 13.34 \\
\hline$H H I$ & 52.92 & 57.97 & 68.01 & 73.74 & 71.35 & 66.53 & 72.91 & 79.83 & 81.26 & 81.92 & 87.89 & 93.36 \\
\hline
\end{tabular}

Source: Bisnode (2015), Ministry of Agriculture of the Czech Republic $(2008,2015)$ - own calculation

Table 4: Concentration in the Czech food and beverages industry.

\begin{tabular}{|l|c|r|r|r|r|r|r|r|r|r|r|c|c|}
\hline & & $\mathbf{2 0 0 3}$ & $\mathbf{2 0 0 4}$ & $\mathbf{2 0 0 5}$ & $\mathbf{2 0 0 6}$ & $\mathbf{2 0 0 7}$ & $\mathbf{2 0 0 8}$ & $\mathbf{2 0 0 9}$ & $\mathbf{2 0 1 0}$ & $\mathbf{2 0 1 1}$ & $\mathbf{2 0 1 2}$ & $\mathbf{2 0 1 3}$ & $\mathbf{2 0 1 4}$ \\
\hline CZ-NACE 101 & CR4 & 16.26 & 14.08 & 20.03 & 18.77 & 19.06 & 16.82 & 16.72 & 26.09 & 25.61 & 25.04 & 26.30 & 24.77 \\
\hline & HHI & 110 & 97 & 169 & 151 & 157 & 132 & 139 & 274 & 264 & 258 & 278 & 238 \\
\hline CZ-NACE 102 & CR4 & 16.28 & 16.39 & 20.13 & 65.03 & 49.78 & 65.22 & 54.48 & 53.84 & 87.00 & 84.95 & 84.28 & 83.33 \\
\hline & HHI & 85 & 90 & 161 & 2058 & 1174 & 1958 & 1311 & 1334 & 5331 & 5223 & 5253 & 5497 \\
\hline CZ-NACE 103 & CR4 & 20.98 & 32.97 & 28.41 & 34.68 & 34.16 & 38.72 & 38.58 & 43.27 & 44.45 & 44.39 & 44.93 & 45.32 \\
\hline & HHI & 155 & 395 & 290 & 458 & 451 & 542 & 565 & 744 & 785 & 737 & 741 & 782 \\
\hline CZ-NACE 104 & CR4 & \multicolumn{1}{|c|}{55.01} & 89.51 & 76.39 & 81.34 & 71.98 & 59.76 & 46.26 & 75.92 & 70.80 & 88.27 & 96.24 & 92.53 \\
\hline & HHI & 4212 & 3615 & 2889 & 2894 & 2260 & 1503 & 893 & 2849 & 3573 & 4510 & 6332 & 3389 \\
\hline CZ-NACE 105 & CR4 & 26.72 & 32.76 & 30.40 & 37.65 & 37.79 & 38.05 & 36.85 & 34.72 & 34.13 & 33.20 & 35.16 & 37.83 \\
\hline & HHI & 270 & 399 & 404 & 489 & 494 & 494 & 498 & 472 & 474 & 458 & 459 & 518 \\
\hline CZ-NACE 106 & CR4 & 20.69 & 22.64 & 25.36 & 25.14 & 22.83 & 19.89 & 23.38 & 36.41 & 29.79 & 28.49 & 28.30 & 21.49 \\
\hline & HHI & 213 & 246 & 251 & 305 & 280 & 218 & 347 & 678 & 438 & 405 & 379 & 233 \\
\hline CZ-NACE 107 & CR4 & 31.05 & 25.93 & 33.65 & 25.05 & 29.36 & 30.97 & 24.57 & 34.63 & 34.01 & 39.43 & 29.34 & 26.43 \\
\hline & HHI & 309 & 221 & 353 & 208 & 278 & 306 & 253 & 376 & 370 & 477 & 276 & 195 \\
\hline CZ-NACE 108 & CR4 & 44.91 & 38.01 & 31.12 & 37.62 & 35.34 & 31.89 & 34.24 & 34.24 & 37.87 & 40.37 & 37.36 & 36.50 \\
\hline & HHI & 669 & 494 & 328 & 474 & 437 & 400 & 384 & 396 & 464 & 514 & 489 & 464 \\
\hline CZ-NACE 109 & CR4 & 13.04 & 14.94 & 26.23 & 19.71 & 12.58 & 15.14 & 36.92 & 37.60 & 45.38 & 45.24 & 41.90 & 56.40 \\
\hline & HHI & 101 & 119 & 297 & 234 & 103 & 146 & 879 & 771 & 860 & 868 & 816 & 1648 \\
\hline CZ-NACE 110 & CR4 & 32.82 & 38.72 & 40.61 & 43.43 & 40.99 & 42.11 & 42.01 & 42.19 & 42.88 & 42.53 & 45.42 & 43.58 \\
\hline & HHI & 409 & 623 & 698 & 803 & 706 & 745 & 769 & 761 & 784 & 759 & 840 & 821 \\
\hline
\end{tabular}

Source: Bisnode (2015), Ministry of Agriculture of the Czech Republic $(2008,2015)$ - own calculation

Table 5: Subsectoral CR4 (in \%) and HHI over years 2003-2014. 


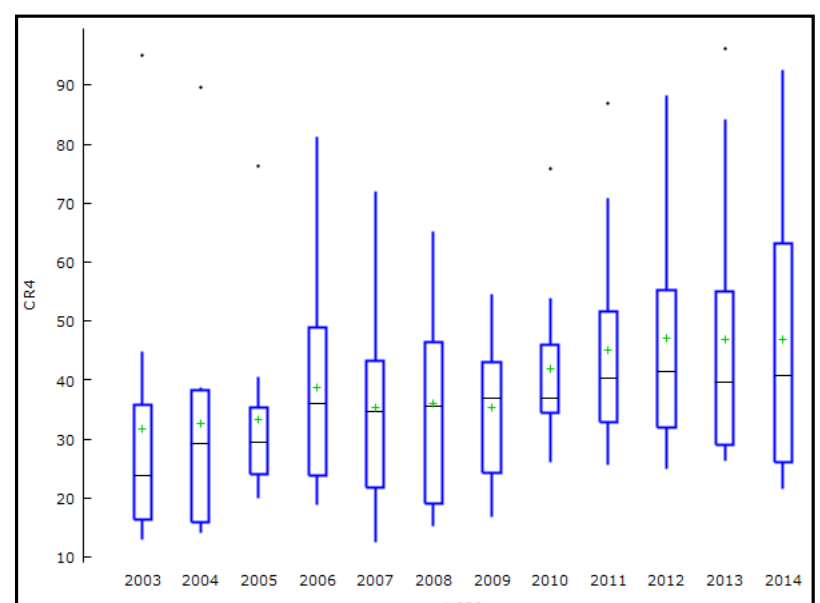

Source: Bisnode (2015), Ministry of Agriculture of the Czech Republic (2008, 2015) - own processing

Figure 1: Subsectoral $C R 4$ distribution across time (CR4 in \%).

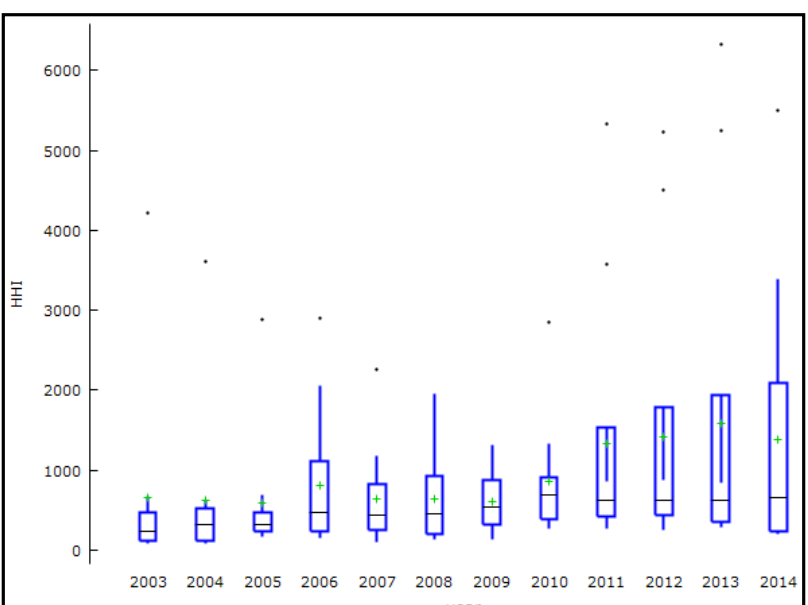

Source: Bisnode (2015), Ministry of Agriculture of the Czech Republic (2008, 2015) - own processing

Figure 2: Subsectoral HHI distribution across time.

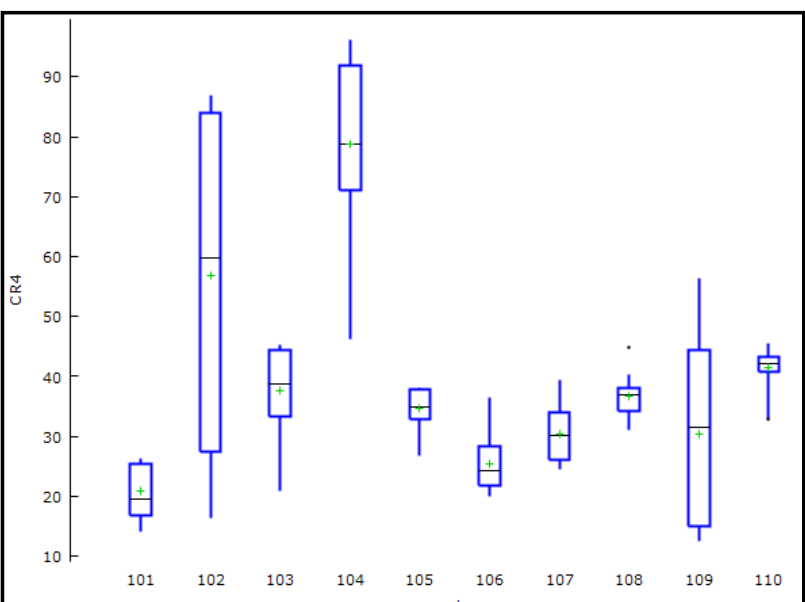

Source: Bisnode (2015), Ministry of Agriculture of the Czech Republic $(2008,2015)$ - own processing

Figure 3: CR4 distribution across subsectors in the period 2004-2014 (CR4 in \%). 


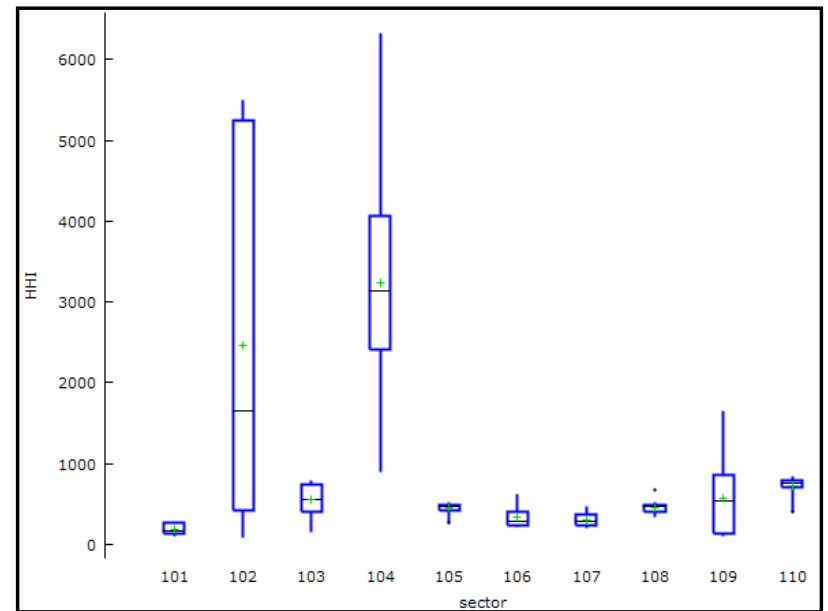

Source: Bisnode (2015), Ministry of Agriculture of the Czech Republic (2008, 2015) - own processing

Figure 4: HHI distribution across subsectors in the period 2004-2014.

From Figures 3 and 4 it is obvious, that the development of both $C R 4$ and $H H I$ differs across sectors. During the observed period the market concentration increased significantly, especially in the sector of processing and preserving of fish and fish products (CZ-NACE 102) - CR4 increased from $16.28 \%$ in 2003 to $83.33 \%$ in 2014 , and in the sector of manufacture of prepared animal feeds (CZ-NACE 109) - CR4 increased from $13.04 \%$ in 2003 to $56.40 \%$ in 2014 . It is worth mentioning the fact that the sector of processing and preserving of fish and fish products (CZ-NACE 102) is the least significant food sector in the Czech Republic (the share of the sector revenues on the revenues of the whole Czech food industry in 2014 was only $0.70 \%$ ), and the import is significant in this sector (Ministry of Agriculture of the Czech Republic, 2008; Ministry of Agriculture of the Czech Republic, 2015), which indicate significant lowering of the value of the concentration ratio $C R 4$ after foreign trade adjustment. The sector of manufacture of vegetable and animal oils and fats (CZ-NACE 104) also shows higher variability of the level of the market concentration during the observed period - it is not caused by increasing trend during the whole period, but it is due to lower values of concentration indicators in years 2008 and 2009 (in these years the largest company, whose market share was around $40 \%$ in 2007 , was transformed into several new enterprises).

Table 6 shows results of the estimation of absolute $\beta$-convergence model in the Czech food and beverages industry. The estimated coefficient for market concentration is negative (which implies $\beta_{l}>0$ ); therefore, there is an absolute convergence of market concentration in the long run and the market concentration tends to converge to one and the same value for all sectors of the Czech food and beverages industry. The results are in harmony e.g. with the findings of Setiawan et al. (2012), who investigated the Indonesian food industry.

The variability of particular sectors concentration decreases, which is also confirmed by Tables 7 and 8 . In sectors with relatively low market concentration in 2003, the values of concentration increased rapidly after 2003 - especially in the sector of fish processing (CZ-NACE 102), in the sector of manufacture of animal feed (CZ-NACE 109) and in the sector of processing of vegetable and fruits (CZ-NACE 103), as seen in Table 7. On the contrary, from Table 8 it is obvious that the most concentrated sectors tend to change slowly over time and the concentration in some sector even declined - namely in the sector of bakery products (CZ-NACE 107) and in the sector of manufacture of other food products (CZ-NACE 108).

The analysis has shown that the average growth rate of market concentration in the observed period was higher among less concentrated sectors in the initial period compared to more concentrated sectors in the initial period, where there was only a slight increase or even decrease in the level of concentration. 


\begin{tabular}{|c|c|c|}
\hline \multirow[t]{2}{*}{ Independent Variable } & Dependent Variable: $C R 4$ & Dependent Variable: $H H I$ \\
\hline & Coefficients & Coefficients \\
\hline \multirow[t]{2}{*}{ Constant } & 0.24628 & 0.48086 \\
\hline & $(0.07877)$ & $(0.16537)$ \\
\hline \multirow[t]{2}{*}{$\operatorname{Ln} C R 4 \ldots\left(-\beta_{1}\right)$} & $-0.06351 * *$ & \\
\hline & $(0.02369)$ & \\
\hline \multirow[t]{2}{*}{ LnHHI... $\left(-\beta_{P}\right)$} & & $-0.07091 * *$ \\
\hline & & $(0.02879)$ \\
\hline R-squared & 0.4733 & 0.4311 \\
\hline F-statistic & $7.1898 * *$ & $6.0629 * *$ \\
\hline p-value & 0.0279 & 0.0392 \\
\hline
\end{tabular}

Note: Standard Errors are in parenthesis, $* * *$ stat. significance at $1 \%$ level, $* *$ stat. significance at $5 \%$ level, * stat. significance at $10 \%$ level.

Source: Bisnode (2015), Ministry of Agriculture of the Czech Republic (2008, 2015) - own calculation Table 6: Absolute convergence of market concentration in the Czech food and beverages industry.

\begin{tabular}{|c|c|c|c|c|c|c|}
\hline \multirow{2}{*}{ Sector } & \multicolumn{2}{|c|}{ CR4 } & \multirow{2}{*}{$\begin{array}{l}\text { Average } \\
\text { Change }\end{array}$} & \multicolumn{2}{|c|}{$H H I$} & \multirow{2}{*}{$\begin{array}{l}\text { Average } \\
\text { Change }\end{array}$} \\
\hline & 2003 & 2014 & & 2003 & 2014 & \\
\hline CZ-NACE 109 & $13.04 \%$ & $56.40 \%$ & $12.98 \%$ & 101.34 & 1647.72 & $26.16 \%$ \\
\hline CZ-NACE 101 & $16.26 \%$ & $24.77 \%$ & $3.57 \%$ & 109.90 & 237.90 & $6.65 \%$ \\
\hline CZ-NACE 102 & $16.28 \%$ & $83.33 \%$ & $14.58 \%$ & 85.46 & 5497.42 & $41.48 \%$ \\
\hline CZ-NACE 106 & $20.69 \%$ & $21.49 \%$ & $0.32 \%$ & 213.41 & 233.12 & $0.74 \%$ \\
\hline CZ-NACE 103 & $20.98 \%$ & $45.32 \%$ & $6.63 \%$ & 155.18 & 782.17 & $14.43 \%$ \\
\hline
\end{tabular}

Source: Bisnode (2015), Ministry of Agriculture of the Czech Republic (2008, 2015) - own processing Table 7: Average change of market concentration in less concentrated sectors in 2003.

\begin{tabular}{|c|c|c|c|c|c|c|}
\hline \multirow{2}{*}{ Sector } & \multicolumn{2}{|c|}{ CR4 } & \multirow{2}{*}{$\begin{array}{l}\text { Average } \\
\text { Change }\end{array}$} & \multicolumn{2}{|c|}{$H H I$} & \multirow{2}{*}{$\begin{array}{l}\text { Average } \\
\text { Change }\end{array}$} \\
\hline & 2003 & 2014 & & 2003 & 2014 & \\
\hline CZ-NACE 104 & $95.01 \%$ & $92.53 \%$ & $-0.22 \%$ & 4212.18 & 3388.67 & $-1.80 \%$ \\
\hline CZ-NACE 108 & $44.91 \%$ & $36.50 \%$ & $-1.72 \%$ & 668.79 & 463.80 & $-3.00 \%$ \\
\hline CZ-NACE 110 & $32.82 \%$ & $43.58 \%$ & $2.39 \%$ & 409.18 & 821.35 & $5.98 \%$ \\
\hline CZ-NACE 107 & $31.05 \%$ & $26.43 \%$ & $-1.33 \%$ & 308.84 & 195.47 & $-3.74 \%$ \\
\hline CZ-NACE 105 & $26.72 \%$ & $37.83 \%$ & $2.94 \%$ & 269.57 & 517.73 & $5.59 \%$ \\
\hline
\end{tabular}

Source: Bisnode (2015), Ministry of Agriculture of the Czech Republic (2008, 2015) - own processing Table 8: Average change of market concentration in more concentrated sectors in 2003.

\section{Conclusions}

The paper has investigated the trend of market concentration in the Czech food and beverages industry in the period 2003-2014. The concept of convergence was applied in order to draw conclusions as to what future development of market structures within food and beverages industry is likely.

The results of the analysis show that the market concentration in the Czech food and beverages industry has increased on average in the period covered by the data but the situation is different in particular sectors. The level of concentration has grown the most in the sectors with relatively low concentration in the initial year of observation, i.e. 2003 , in comparison with the most concentrated sectors in 2003, where only a small increase or even decrease of concentration was observed. These observations were validated by the application of the absolute $\beta$-convergence model - initially low-concentrated markets tend to concentrate faster until they catch up with the high-concentrated ones and in the long run, expected concentration indicators are the same for all sectors, independently of their initial value. However, the convergence to the steady state is an extremely slow process, as pointed out by de la Fuente (2000).

Nevertheless, the level of concentration 
of the Czech food market is still low in comparison with the subsequent stage of the commodity chain, i.e. retail, which may cause a worse market position of food processors and disproportions in profits of processors and traders. Therefore, increasing concentration on the food processing market may help processors to better face the concentrated retail and to have better bargaining position when negotiating prices. On the contrary, the processors' higher market power due to the increased market concentration may lead to the abuse of this market power relative to farmers, e.g. downward pressure on prices of agricultural producers, which can negatively influence the Czech agriculture. As mentioned by Swinnen and Maertens (2007), farmers may benefit from competition between processing firms due to more equal rent sharing reflected in higher producer prices and more services to farmers. Since the food industry is an important part of the commodity vertical with significant influence on the performance and competitiveness of the Czech agriculture, policies should be designed for development of a market structure to promote competition.
The development of the market structure at particular stages of the commodity chain influences the formation of all price levels within the chain and has an impact on all participants in the production of food products - suppliers of raw materials for food production, food manufacturers, retail and wholesalers, consumers, policymakers and also state control authorities. Therefore, this area of research is important in agribusiness and a deeper view on the impact of market structure development on the price levels and performance of agribusiness enterprises in the long run would be interesting.

\section{Acknowledgements}

The paper was developed within the Research Project of MENDELU in Brno, MSM 6215648904 , as a part of the solution to thematic direction No. 4 "The development tendency of agribusiness, forming of segmented markets within commodity chains and food networks in the process of integration, globalization and changes of agrarian policy".

Corresponding author:

Ing. Ivana Blažková, Ph.D.

Department of Regional and Business Economics, Faculty of Regional Development and International Studies, Mendel University in Brno, Zemědělská 1, 61300 Brno, Czech Republic

Phone: +420 545136 405, E-mail: blazkova@mendelu.cz

\section{References}

[1] Bečvářová, V. (2007) "Shaping agribusiness and its impact on the competitive environment of agricultural enterprises", IAAE-104 ${ }^{\text {th }}$ EAAE Seminar - Agricultural Economics and Transition: What was expected, what we observed, the lessons learned, September 6-8, Corvinus University of Budapest, Budapest, Hungary [Online]. Available: http://ageconsearch.umn.edu/bitstream/7824/1/ sp07be01.pdf [Accessed: 25 October 2016].

[2] Bisnode (2015) “Database Albertina - Gold Edition”. Praha: Bisnode Česká republika, a.s.

[3] Blažková, I. and Chmelíková, G. (2014) "Market Concentration as a Precondition for Higher Competitiveness of the Czech Food Industry", INPROFORUM: Investment Decision-Making in the Period of Economic Recovery, November 6-7, University of South Bohemia in České Budějovice, pp. 121-126. ISBN 978-80-7394-484-1.

[4] Boehlje, M., Roucan-Kane, M. and Bröring, S. (2011) "Future agribusiness challenges: Strategic uncertainty, innovation and structural change", International Food and Agribusiness Management Review, Vol. 14, No. 5, pp. 53-82. ISSN 1096-7508.

[5] Clarke, R., Davies, S., Dobson, P. and Waterson, M. (2002) "Buyer power and competition in European food retailing". Edward Elgar Publishing, Cheltenham, UK, 220 p. ISBN 1-84064-685-3.

[6] Čechura, L., Žáková Kroupová Z. and Hockmann, H. (2015) "Market Power in the European Dairy Industry", AGRIS on-line Papers in Economics and Informatics, Vol. 7, No. 4, pp. 39-47. ISSN 1804-1930. 
[7] Daniels, P. et al. (2008) “An Introduction to Human Geography: Issues for the $21^{\text {st }}$ Century”. Pearson Education Ltd., Harlow, 544 p. ISBN 978-0-13-205684-7.

[8] De la Fuente, A. (2000) “Convergence Across Countries and Regions: Theory and Empirics”. CEPR Discussion Paper No. 2465. ISSN 0265-8003.

[9] Dobson, P. W., Waterson, M. and Davies, S. W. (2003) "The patterns and implications of increasing concentration in European food retailing”, Journal of Agricultural Economics, Vol. 54, No. 1, pp. 111-125. ISSN 1477-9552. DOI 10.1111/j.1477-9552.2003.tb00053.x

[10] Dries, L., Reardon, T. and Swinnen, J. F. M. (2004) "The rapid rise of supermarkets in Central and Eastern Europe: Implications for the agrifood sector and rural development". Development policy review, Vol. 22, No. 5, pp. 525-556. ISSN 1467-7679. DOI 10.1111/j.1467-7679.2004.00264.X

[11] MacDonald, J. M. and Korb, P. (2011) "Agricultural Contracting Update: Contracts in 2008", EIB-72, U.S. Department of Agriculture, Econ. Res. Serv., 35 p. [Online]. Available: http://ageconsearch.umn.edu/bitstream/101279/2/EIB72.pdf [Accessed: 16 June 2015].

[12] McCorriston, S. (2002) "Why Should Imperfect Competition Matter to Agricultural Economists?", European Review of Agricultural Economics, Vol. 29, No. 3, pp. 349-372. ISSN 1464-3618. DOI 10.1093/eurrag/29.3.349.

[13] Ministry of Agriculture of the Czech Republic (2008) "Panorama of the food industry 2007 - in Czech (Panorama potravinářského průmyslu 2007)”, Ministry of Agriculture, Prague, p. 108. [Online]. Available: http:/eagri.cz/public/web/mze/potraviny/publikace-a-dokumenty/panoramapotravinarskeho-prumyslu/panorama-potrav-prumyslu-2007.html [Accessed: 23 March 2015].

[14] Ministry of Agriculture of the Czech Republic (2015) "Panorama of the food industry 2014 - in Czech. (Panorama potravinářského průmyslu 2014)", Ministry of Agriculture, Prague, p. 76. [Online]. Available: http://eagri.cz/public/web/mze/potraviny/publikace-a-dokumenty/panoramapotravinarskeho-prumyslu/panorama-potravinarskeho-prumyslu-2013.html [Accessed: 10 June $2015]$.

[15] Reardon, T., Timmer, P., Barrett, C. B. and Berdgué, J. (2003) "The Rise of Supermarkets in Africa, Asia, and Latin America", American Journal of Agricultural Economics, Vol. 85, No. 5, pp. 1140-1146. ISSN 1467-8276. DOI 10.1111/j.0092-5853.2003.00520.x.

[16] Regmi, A. and Gehlhar, M. (2005) "New directions in global food markets", AIB-794, U.S. Department of Agriculture, Econ. Res. Serv., p. 75. [Online]. Available: http://umr-moisa.cirad.fr/ content/download/5290/36277/version/1/file/New+directions+in+global+food+markets+2005-02. pdf [Accessed: 4 May 2015].

[17] Rogers, R.T. (2001) "Structural Change in U.S. Food Manufacturing, 1958-1997", Agribusiness, Vol. 17, No. 1, pp. 3-32. ISSN 1520-6297. DOI 10.1002/1520-6297(200124)17:1<3::AIDAGR1001>3.0.CO;2-1.

[18] Řezbová, H. Maitah, M. and Sergienko, O. I. (2015) "EU Quota Sugar Market Concentration - the Main Drivers of EU Sugar Market", AGRIS on-line Papers in Economics and Informatics, V ol. 7, No. 4, pp. 131-142. ISSN 1804-1930.

[19] Saitone, T. L. and Sexton, R. J. (2010) "Product Differentiation and Quality in Food Markets: Industrial Organization Implications", Annual Review of Resource Economics, Vol. 2, pp. 341-368. ISSN 1941-1340. DOI 10.1146/annurev.resource.050708.144154.

[20] Sala-i-Martin, X. (1996) "The classical approach to convergence analysis", The Economic Journal, Vol. 106, No. 437, pp. 1019-1036. ISSN 1468-0297. DOI 10.2307/2235375.

[21] Setiawan, M., Emvalomatis, G. and Lansink, A. O. (2012) "Industrial concentration and pricecost margin of the Indonesian food and beverages sector", Applied Economics, Vol. 44, No. 29, pp. 3805-3814. ISSN 1466-4283. DOI 10.1080/00036846.2011.581220.

[22] Sexton, R. J. (2012) "Market Power, Misconceptions and Modern Agricultural Markets", American Journal of Agricultural Economics, Vol. 95, No. 2, pp. 209-219. ISSN 1467-8276. DOI 10.1093/ajae/aas 102. 
[23] Shervani, T. A., Frazier, G. and Challagalla, G. (2007) "The moderating influence of firm market power on the transaction cost economics model: an empirical test in a forward channel integration context", Strategic Management Journal, Vol. 28, No. 6, pp. 635-652. ISSN 1097-0266. DOI: $10.1002 /$ smj.585.

[24] Swinnen, J. F. and Maertens, M. (2007) "Globalization, privatization, and vertical coordination in food value chains in developing and transition countries". Agricultural economics, Vol. 37 , No. 1, pp. 89-102. ISSN 1574-0862. DOI 10.1111/j.1574-0862.2007.00237.x.

[25] Swinnen, J. F. M. and Vandeplas, A. (2010) "Market power and rents in global supply chains". Agricultural Economics, Vol. 41, No. s1, pp. 109-120. ISSN 1574-0862. DOI 10.1111/j.1574-0862.2010.00493.x.

[26] U.S.Department of Justice and the Federal Trade Commission(2010) “Horizontal Merger Guidelines". p. 34. [Online]. Available: http://www.justice.gov/sites/default/files/atr/legacy/2010/08/19/hmg2010.pdf [Accessed: 17 June 2015].

[27] Viscusi, W. K., Harrington, J. E. and Vernon, J. M. (2005) "Economics of Regulation and Antitrust", MIT press, 927 p. ISBN-13: 978-0-262-22075-0.

[28] Zemplinerová, A. and Stibal, J. (1994) "Evolution and Efficiency of Concentration: Manufacturing Industries in the Czech Economy 1989-1992”. CERGE-EI Working Paper Series, No. 52, p. 55. [Online]. Available: http://papers.ssrn.com/sol3/papers.cfm?abstract_id=1558098 [Accessed: 20 June 2013]. 